\title{
Characterisation and growth kinetics studies of caffeine-degrading bacterium Leifsonia sp. strain SIU
}

\begin{abstract}
Caffeine is an important naturally occurring compound that can be degraded by bacteria. Excessive caffeine consumption is known to have some adverse effects. We isolated a new bacterium from agriculture soil. The bacterium was tested for its ability to utilise caffeine as the sole carbon and nitrogen source. The isolate was Gram-negative and was identified as Leifsonia sp. strain SIU based on $16 \mathrm{~S}$ rRNA gene sequencing. It showed $97.16 \%$ of $0.3 \mathrm{~g} / \mathrm{L}$ caffeine degradation in $48 \mathrm{~h}$ when caffeine was used as a sole carbon and nitrogen source. The bacterial growth and degradation at $0.3 \mathrm{~g} / \mathrm{L}$ caffeine concentration occurred optimally, using $5 \mathrm{~g} / \mathrm{L}$ sucrose, $0.4 \mathrm{~g} / \mathrm{L}$ ammonium chloride, at a temperature between 25 and $30^{\circ} \mathrm{C}$ and $\mathrm{pH}$ of 6.0ї 7.0. The Luong model best describes the kinetics of the strain growth. The values for the maximum specific growth rate $(\varepsilon \max )$, the Monod half saturation constant (K S ), the maximum substrate inhibitory concentration and $\mathrm{n}$ are $0.049 \mathrm{~h} \overline{\mathrm{l}} 1,0.0021 \mathrm{mg} / \mathrm{L}, 25.0 \mathrm{~g} / \mathrm{L}$ and 1.562 , respectively. These bacterial features make it an ultimate means for caffeine bioremediation. This is the first report of caffeine degradation by Leifsonia sp. strain SIU.
\end{abstract}

Keyword: Caffeine; Degradation; Kinetics modelling; Leifsonia sp. 